\title{
Research on the Construction of Network Ideological and Political Education Platform in Colleges and Universities Under the Background of Big Data
}

\begin{abstract}
Siqi Zhang*
Research Center of Ideological and Political Education, Northeast Normal University, Changchun 130000, Jilin Province, China

*Corresponding author: Siqi Zhang, 272787455@qq.com

Abstract: In the context of big data, ideological and political education in colleges and universities has become particularly important. Teachers should actively introduce new ideas and methods of ideological and political education, so as to stimulate students' interest in ideological and political learning as well as develop their ideological and political level ${ }^{[1]}$. In view of this, this study explores the construction of college network ideological and political education platform under the background of big data and proposes several strategies for reference.
\end{abstract}

Keywords: Big data; Colleges and universities; Network ideological and political education; Platform construction

Publication date: December 2021; Online publication: January 24, 2022

\section{Introduction}

This is an era guided by data. The internet has played an important role in the construction of people's spiritual home. Therefore, when colleges and universities carry out ideological and political education, they should pay attention to the integration of big data and internet technology, gradually construct a network ideological and political education platform, realize the synergy between education and the times, as well as help students form healthy values.

2. Significance of the construction of network ideological and political education platform in colleges and universities under the background of big data

\subsection{Meets the development needs of the socialist era}

From the perspective of big data, the previous ideological and political education model faces difficulty in meeting the development requirements of the times. Although some colleges and universities have tried to innovate the education model, the actual effect is unsatisfactory. This is because they have failed to rationally utilize emerging technologies. In addition, from the 2018 Data Center Survey, the keywords that are often searched on the internet by college and university students include "star gossip," "negative news," and "entertainment games." Therefore, it is urgent to carry out efficient ideological and political education. Through big data, information technology, and other means, colleges and universities should build a more targeted and interesting ideological and political education platform, so as to realize the effective governance of the ecology of ideological and political education in colleges and universities ${ }^{[2]}$. With the continuous improvement of the ideological and political education platform, teachers can gradually grasp 
the pulse of the times and integrate ideological and political education work into the life of college and university students, so as to ensure that the network ideological and political education platform can be more effective and in line with the development needs of the times, thus improving the efficiency of education.

\subsection{Meets the requirements of education in the new era}

In the previous ideological and political education, colleges and universities usually work in the form of combining theory with practice. The theoretical part is generally taught in class, while the practical part requires college students to participate in the form of social activities. However, due to the ancient approach and the lack of interest in the process, the enthusiasm of students to participate in these activities is poor. However, the network ideological and political education platform in the context of big data is different. It can analyze the characteristics of each student and locate different groups through their network usage habits and keywords, so as to provide targeted and effective services to these students. Big data can infiltrate into the network ideological and political education platform, classify students according to their learning characteristics, methods, and habits, as well as promote the accuracy of ideological and political education, which is extremely important to improve the quality of college and university students.

\section{The construction orientation of network ideological and political education platform in colleges and universities under the background of big data}

\subsection{Chain-oriented}

In the current network environment, there is no clear boundary between students and social personnel. Therefore, when constructing the ideological and political education platform, colleges and universities should pay attention to the division of different groups and ensure the dominance of students on the education platform, so as to form a "chain-oriented" construction.

From the perspective of big data, the network ideological and political education platform can limit the types of groups by means of information technology. At the same time, teachers should fully explore the potential and valuable social information on the network as well as steer it accurately in line with the characteristics of each student ${ }^{[1]}$. By optimizing information from the source, controlling information in content, and creating an intelligent, systematic, and scientific chain in combination with data information, such as after-school feedback, the accurate control of education and the interest of students can be realized and stimulated, respectively.

\subsection{Problem-oriented}

From the perspective of big data, there are two major problems in the construction of network ideological and political education platform in colleges and universities. One of the problems is the processing of "mimicry" information; the second is the "self" infiltration of values with the help of network channels. With the help of big data identification, students are exposed to a lot of information every day, realizing that "what they think is what they see." However, the outlook on life and world outlook of these students have not taken shape, and an efficient information processing system has not been established ${ }^{[2]}$. Their information identification and information processing are not comprehensive enough; hence, they are easily affected by negative information, resulting in serious adverse consequences. Therefore, when constructing the network ideological and political education platform, it is necessary to be problem-oriented, systematically help college students sort out social information, grasp their ideological dilemma, and improve the quality of education. 


\subsection{Effect-oriented}

No matter what type of education is carried out, the effect should be taken as the core of the work. Students should be encouraged to deepen their understanding about the content of their studies and developed into better talents. In the construction of network ideological and political education platform, all forms, means, and contents should be effect-oriented. Therefore, teachers should make effort from the following points: first, the platform should be rich in content and displayed in a vivid manner to attract the attention of students; second, big data should be used to extend information in line with the topics concerned by college students, so as to gain favor from students to continue using the platform; third, emphasis should be on the collection of data and information as teachers can evaluate the behavior, thought, and attitude of the students, understand the characteristics of each student, and implement accurate user portraits for them, so as to significantly improve the effect of education.

\section{Construction strategy of network ideological and political education platform in colleges and universities under the background of big data}

\subsection{Form a "big data + big ideological and political education" model and integrate various functions}

When constructing the network ideological and political education platform, teachers should analyze from the macro level and form a "big data + big ideological and political education" model. For instance, teachers can establish functional blocks, such as education and teaching, psychological service, as well as ideological and political practice, on the platform in the form of applications and WeChat public platforms to effectively integrate the ideological and political data on the platform. After completing the principal construction, teachers can use big data to analyze the students' access rate and attention duration in each module, and then dynamically adjust the content to reduce the repetition rate and improve the richness of the content on the platform. In addition, colleges and universities can add educational administration management, score query, campus card recharge, and other functions to the education platform, so as to realize the efficient use of the platform, enhance the dependence of students on this education platform, as well as imperceptibly achieve the effect of ideological and political education.

\subsection{Establish multi-level teams and improve network ideological and political work}

From the perspective of big data, when colleges and universities carry out the construction of the education platform, they need to establish multi-level teams to realize the effective management of the platform. First, the management team is generally composed of excellent party members in colleges and universities. The responsibilities of the team include the supervision of the contents on the platform, carrying out in-depth interaction with students, and dealing with the questions raised by these students in the Q\&A module in a timely manner. Second, the teaching and research team is composed of ideological and political experts. The main responsibility of the team is to investigate the existing ideological and political problems of college and university students as well as put forward targeted and effective solutions to these problems ${ }^{[2]}$. The third is the big data support team. This team is mainly composed of computer teachers. The responsibilities of these teachers are to maintain the data security of the platform and effectively sort and analyze the platform data. The fourth is the practice team. The members of this team are mainly counselors and ideological and political teachers. Their responsibility is to reasonably guide opinion leaders in line with the ideological changes of college and university students, so as to realize the effective development of ideological and political education. The fifth is the team of college students. The members of this team are mainly student cadres and the members of the league. They act as a bridge between the students and the education platform. Through the establishment of multi-level teams, the construction level of the network ideological and political education platform can be improved significantly. 


\subsection{Optimize the interaction mode to realize deep expression}

No matter what form of ideological and political education is carried out in universities, a good communication and interaction mechanism is the foundation. In the construction of network ideological and political education platform in colleges and universities, teachers can start from several aspects to ensure the rationality and scientificity of the interaction and realize the in-depth expression of information. First, make full use of big data to realize teacher-student interaction. When designing the education platform, a special interactive mechanism should be established to place students and teachers in the same module so that they can communicate anonymously ${ }^{[1]}$. This would help college students speak boldly, allow teachers to better understand the students' opinions, as well as realize the interaction and debate between teachers and students. In addition, data analysis can be carried out in the background with regard to the frequency and keywords in the interaction, so as to direct the follow-up ideological and political lesson. Second, establish an interworking communication mode. The education platform can connect the microblogs of teachers, students, and leaders. In that way, teachers and leaders would be able to understand the ideological changes of the students, so as to timely modify the educational content. Third, enrich the forms of dialogues. On the education platform, an online and offline interaction mechanism can be established, certain online problems can be introduced offline, and dialogues can be carried out in the form of salons and tea parties, so as to achieve the effect of in-depth expression and communication.

\subsection{Enrich software and hardware resources as well as carry out scientific layout}

The construction of network ideological and political education platform in colleges and universities has a diverse content, involving a large number of personnel and equipment. This requires teachers to make reasonable planning before construction, make rational use of software and hardware resources, as well as realize the scientific layout of the platform construction. In order to achieve this goal, it is imperative to first realize data sharing. On the basis of smart campus, colleges and universities should expand data, realize efficient sharing of data information, and lay a data foundation for the platform construction. Second, the identity management and authentication system should be optimized. In consideration of the access needs of different users, different permissions can be set for platform users to meet everyone's access objectives. The third is to optimize the service system. When constructing the education platform, it is necessary to ensure the perfection of various functions and highlight the practicability of the education platform. Finally, the construction of a security system should be emphasized. There are a lot of data information in the education platform. Therefore, it is necessary to strengthen the construction of a security system to avoid information leakage, so that both students and teachers can rest assured in using the network ideological and political education platform.

\section{Conclusion}

In conclusion, from the perspective of big data, if colleges and universities wish to realize the construction of a high-level network ideological and political education platform, they should integrate functions from "big data + big ideological and political education," establish multi-level teams and improve network ideological and political work, optimize the interaction mode to realize deep expression, enrich software and hardware resources, as well as carry out scientific layout, so as to further improve the construction quality of network ideological and political education platform in colleges and universities as well as lay a solid foundation for the follow-up ideological and political education.

\section{Disclosure statement}

The author declares that there is no conflict of interest. 


\section{References}

[1] Qian X, 2020, Research on Collaborative Education of Ideological and Political Work in Colleges and Universities in the Era of Big Data, University of Electronic Science and Technology.

[2] Song G, 2018, Feasibility Analysis of Building a Network Platform for Ideological and Political Education in Colleges and Universities in the Era of "Big Data". Research on Ideological and Political Education, 34(2): 155-157. 